\title{
2 \\ Fostering affinity through dreams and origin ritual practices among the Gumay of South Sumatra, Indonesia
}

\section{Minako Sakai}

\section{Introduction}

The Gumay people are a highland Malay-speaking ethnic group in the province of South Sumatra in Indonesia. ${ }^{1}$ The most fundamental emotion for the Gumay is their respect for their ancestors and the origin villages associated with their ancestors, which are known as dusun laman. Remembering one's origin (Sakai 1997, 2002, 2006, 2009) is the most important obligation as a Gumay. Remembering one's origin means maintaining their relationship with the dusun laman through regular visits. Dusun laman generally refers to a hamlet to which Gumay people, living and deceased, belong, and is a place strongly affiliated with Gumay origins. Affinity and strong emotion are evoked when Gumay people return to their dusun laman. They celebrate their link to a dusun laman by holding

1 Before 2000, Gumai was the common spelling used in official documents. However, after the democratisation of Indonesia and the revival of regional culture, Gumay has become the preferred spelling. I have used Gumai in my earlier research publications, but, reflecting the change in the field, I use Gumay in this chapter. 
a sedekah or ritual feast gathering. People express their happiness, safety and peacefulness when they return to their dusun laman. Thus, closeness and affection are not limited to expressions of romantic love.

The aim of this chapter is to explain how people's affinity with their dusun laman is expressed through kinship relations and emotional categories such as dreams (mimpi), visions (ginaan) or feelings (perasan). Dreams and visions often convey conscious and unconscious affinity with the origin village and messages in dreams and visions frequently lead to the formation of figurative kinship terms to revive and strengthen their links to dusun laman. Such figurative relations are not limited to Gumay people, but also may be applied to non-Gumay people such as myself who have developed strong emotional ties with Gumay people.

I conducted 20 months of fieldwork in Gumay Talang, located near the city of Lahat, in Indonesia's South Sumatra Province. I lived with two important Gumay families throughout this period, and was adopted as their daughter. My figurative adoption took place because I developed strong relations, as I will outline in two of the case studies in this chapter. Even after my initial fieldwork, I have maintained close contact with these two families over the past two decades through short visits and, increasingly, through the use of mobile phones. I made a short visit to Gumay Talang in August and in November 2015 to update and check my ethnographic data.

The structure of this chapter is as follows: the first section will provide an overview of the South Sumatran highlands and the origin stories of the Gumay. The second section will discuss the ways Gumay formalise affinity and affection including kinship relations and the ritual practice of sedekah. The third section consists of case studies that illustrate how affinity and affection are embodied in kinship relations, ritual practices and spatial connections with, and expressed desire to return to, one's origins (dusun laman). I will argue that dreams and feeling provide an opportunity for the Gumay to remember their affinity with dusun laman, despite the increasing influence of Islamisation in the everyday life of the Gumay (Sakai 1997, 2002, 2009, 2017a, 2017b). 


\section{Overview}

There are three main clusters of Gumay villages in South Sumatra Province: Gumay Ulu, Gumay Lembak and Gumay Talang. These names were originally used as an administrative unit (marga), prior to the 1980s. All three clusters are located in the district of Lahat. Gumay Talang, the newest cluster of 14 villages, is about $15 \mathrm{~km}$ from the city of Lahat. These 14 villages became an administrative unit known as kecamatan (subdistrict) around 2008. While there is no specific statistical record available regarding the total Gumay population in Indonesia, the 2010 census shows the population of Gumay Talang was 9,804. ${ }^{2}$ This population size is small for Indonesia, but an ethnographic study of Gumay is important in understanding the South Sumatran population. This is because Gumay people share general cultural traits of highland Malay speakers in a region in which numerous ethnic groups have long co-resided. For example, Gumay people have ancestral relations with neighbouring Besemah and Semendo people living in South Sumatra Province (Collins 1979: 20-35). Gumay also share general cultural traits with other nearby ethnic groups such as Empat Lawang, Belido, Lintang and Kikim in South Sumatra and Bengkulu and Lampung.

The name Gumay is widely known in the South Sumatra, as they are believed to be the oldest ethnic group in the region. The Gumay people claim to have migrated from Palembang and spread widely along nine major rivers (Batang Hari Sembilan) in southern Sumatra. According to their oral narratives, their founding ancestor, Diwe Gumay, was the first to descend from the Bukit Segungtang (Segungtan Hill) in Palembang on the night known as Malam Empat Belas. The descendants of the founding Gumay have moved upstream along major rivers, looking for fertile land and have settled in the highland areas near Lahat. Gumay people have spread through southern Sumatra, as Gumay ancestors have formed alliances with guardians of the important spheres of sea, sky and forest. ${ }^{3}$

The importance of these oral narratives is represented by the continuing practice of the monthly ritual Sedekah Malam Empat Belas (Sakai 2003). The ritual, to commemorate Diwe Gumay's descent, is conducted by the

2 'Lahat (Regency, Indonesia): Population statistics and location in maps and charts', available from: www.citypopulation.de/php/indonesia-admin.php?adm2id=1604 (accessed 7 August 2015). The estimated population in 1994 was 8,281 (Sakai 1997: 44).

3 See Sakai (1997: 45) on Gumay's relationship with the four important spheres. 
Jurai Kebali'an, the most important Gumay ritual specialist, who traces his genealogy to Diwe Gumay. This monthly ritual is considered to be the most important occasion for the Gumay to return to dusun laman and seek blessings from their ancestors.

The term Jurai Kebali'an consists of jurai, which means 'descendants', and kebalian, meaning 'to return'. His house, located in Endikat Ilir village in Gumay Talang, is believed to be the house to which all Gumay descendants should return, and the monthly ritual attracts 200-500 participantspredominantly visitors from outside the immediate cluster of Gumay Talang. The ritual is to ask for blessings from guardians and ancestral spirits so that Gumay descendants will be protected and given an ample livelihood (rezeki). The Jurai Kebali'an conducts a series of rituals as the guardian of this earth (junjungan di bumi) on behalf of his descendants. He is responsible for the wellbeing and livelihood of the Gumay and other ethnic groups in the region. The presentation of offerings and sacrificial animals and the burning of the tree resin benzoin (menyan) constitute the core of this ritual. The majority of the Gumay and other highlanders are cash-crop farmers producing coffee, rubber and agricultural products, and their livelihood sources are closely linked to forests and the land.

Although the upkeep of adat (customs) matters is important for the Gumay, the South Sumatran highlanders are Muslims and Islamisation processes have penetrated into the highlands. On the surface, Islamic values and teaching dominate the ways of life among the Gumay. ${ }^{4}$ Harvest rituals, marriage ceremonies and funerals are all conducted according to Islam. But the importance of ancestors and origin villages continues to influence the majority of the population. Unexpected illnesses, deaths of family members, misfortune and accidents are often linked to a breach of their tradition and customs. Various Gumay ritual specialists, known as Jurai Tue and Mimbar, look after matters related to ancestors-now usually called adat. The succession of these ritual specialists is through genealogical connections and, despite increasing Islamisation in contemporary Indonesia, I have found that younger generations of Gumay have continued to respect and maintain their roles as ritual specialists over the past 20 years of my research (Sakai 2017b).

4 For example, the practice of oral epics known as guritan at the time of mourning among the Besemah people has almost ceased and has been replaced with Islamic Qur'anic recitation of yasinan. See Collins (1998). 
One of the main obstacles to ethnographic research in this region has been secrecy around the knowledge related to ancestors. Only ritual specialists are allowed to have the knowledge of adat matters. Furthermore, calling the names of ancestors is closely linked to invoking the ancestral spirits, and people are generally reluctant to talk about ancestors or genealogies without seeking permission from the ancestors. Talking about Gumay genealogies and ritual practice to a total stranger, such as a foreign anthropologist, was unthinkable until the last Jurai Kebali'an, the late R. A. Rumsyah Amasin, wholeheartedly supported my research in 1994. He was concerned that secrecy would eventually lead to the disappearance of adat knowledge among the Gumay. There was a general view in the South Sumatran highlands that widespread Islamisation had led to the discontinuity of the Besemah descendants (putus jurai), as ritual specialists of the major clans (sumbai) ceased to function in daily matters. Because Pak Rumsyah endorsed my research, I was given permission to observe rituals and talk to the most knowledgeable ritual specialists (Jurai Tue and Mimber). He also asked one of his daughters, Yulia, to accompany me, to show his full support of my research. I still experienced some initial doubts from ritual specialists, but my 20 -month stay in the field certainly contributed to the formation of close relations with the Gumay community, particularly the two Gumay families with whom I was staying. For reasons I discuss in the next section, I was adopted as a daughter by two key Gumay families and my putative family relations opened up my entry to the Gumay community. These were the family of the Jurai Kebali'an in Endikat Ilir village, Pak Rumsyah, and the family of the late Haji Hasan Basri in Lahat city. Haji Hasan Basri, whose mother was from the Lubuk Sepang village of Gumay Lembak, had served as a member of the local parliament for the Golkar Party. His wife had also served as a member of the local parliament for two periods and was actively involved in civil organisations in Lahat. Two of their daughters were working as senior schoolteachers in Lahat and, consequently, the Hasan Basri family was known and well respected in Lahat city. Although Haji Hasan Basri was a Muslim pilgrim and was strongly against un-Islamic practices, he was very interested in knowing the history of the Gumay and their associated rituals. Consequently, he was very supportive of my stay in his house and was a discussant in my research. 


\section{Affinity and affection among the Gumay}

Now let me explain the importance of origins among the Gumay and how genealogical relations are shown and expressed by putative kinship relations through adoption. Dreams are often interpreted as evidence of the existence of mutual strong emotional ties, which justify the formation of putative kinship relations.

Generally speaking, the Gumay can trace their genealogical connections to any of the ancestors. Genealogical knowledge held among the Gumay is bilateral and does not usually include generations above grandparents. The expression nenek empat, puyang delapan (meaning 'four grandparents and eight great-grandparents') defines the scope of genealogical knowledge held among the Gumay. Parents of grandparents and ascending generations are all referred to as ancestors, known as puyang. To distinguish sex, puyang lanang is used for male ancestors and puyang betine is used for female ancestors.

The Gumay select either a particular pair of ancestors or a single ancestor as the Puyang Ketunggalan Keluarge, or the sole family ancestor from whom all descendants have derived. Puyang Ketunggalan Keluarge is the highest or most distant ancestor remembered among these descendants. The selection of the Puyang Ketunggalan Keluarge is rather contingent, determined by the genealogical knowledge shared among descendants. Therefore, who is a descendant of one particular ancestor is not easy to define; rather, it is an individual point of view that determines the ultimate ancestor for each person. ${ }^{5}$ The third ascending generation of puyang is the Puyang Ketunggalan Keluarge, but who is chosen for this position is determined by an individual's genealogical knowledge, ${ }^{6}$ or possibly by a figurative adoption.

\footnotetext{
5 The contingency of origin group membership among the Austronesians is shown by various ethnographic findings. Waterson (1995), for instance, shows how actual membership of a rapuan origin group among the Sadan Toraja of South Sulawesi-can only be manifested through the contribution made to the reconstruction of origin houses.

6 In other parts of Indonesia, a kin group is often formed through relationship to a house. For instance, Waterson (1995: 197) illustrates a case of pa'rapuan of the Sa'dan Toraja of South Sulawesi. People trace their descent from a particular house, which was made by a particular pair of ancestors. The boundaries of membership of pa'rapuan are contingent on the situation and individuals.
} 
Adoption is widely practised among the Gumay. There are two types of adoption: the first is angkat anak, adoption of a child between genealogically related relatives. In this case, it is usually a childless uncle or aunt who adopts one of their nieces or nephews. The second type, which is equally common, is angkat-angkatan or figurative adoption between strangers. This can take place when two individuals share a strong friendship or affinity, and is often formalised after they have shared a loss of family members. The deceased family members may sometimes share the same name, traits or gender. For example, during my fieldwork between 1994 and 1996, I encountered the following case from Gumay Talang. SA, a woman in her 70s in Darmo village, adopted $Y$, a trader in her late 30s who came from Pagar Agung, in Lahat, to sell vegetables in Gumay Talang every day. Y was married and had four children, but she had lost one of her daughters, Tri, a few years earlier. In 1990, SA lost her daughter, Nur, who also had four children, one of whom was named Tri. When SA met Y, SA felt that her daughter was alive and, later, the two women discovered the coincidence of having a daughter named Tri. As a result of this adoption, $\mathrm{Y}$ became a daughter of SA and replaced her deceased daughter. In return, $Y$ was able to regain Tri, her lost daughter, in the newly adopted kinship relation. In summary, both women were able to find a replacement for their deceased daughter through this figurative kinship relation.

My own adoption into two Gumay families also involved a death in both families. First, prior to my arrival, the second daughter of the Jurai Kebali'an, Ayuk Oli, had died of cancer. Before her death, she visited Japan with her husband and children and loved the country. I came from Japan and was almost the same age as Oli and became very close to Yulia, who had been close to Oli. My close relations with the family of the Jurai Kebali'an were witnessed when I went to see the last moment of the Jurai Kebali' an in a Jakarta hospital and attended his funeral in his house. As a result, I was invited to announce my adopted position in 2001 at the monthly ritual. Second, Haji Hasan Basri had lost his second daughter, who died when she was 19 years old. Her death had occurred long before my appearance in their house in the 1990s. My long stay in their family invoked memories of their lost daughter. Without undertaking any official ritual of adoption, I was often introduced as an adopted daughter from his family, and both my parents declared that I had replaced their lost daughter and my relations with them continue. 
There are several reasons adoption is commonly practised, relating to the notion of remembering origins. First, the Gumay dislike not having descendants. If a Gumay dies childless, their life is regarded as unhappy because they do not have a successor in genealogical terms. Having no children is extremely undesirable among the Gumay. To avoid this, childless couples engage in both modern and traditional fertility treatments. If none of the treatments proves effective, the Gumay appoint a nephew or niece as anak angkat (adopted child), their genealogical successor. This adoption does not require the adopted person to cut ties physically or genealogically with his or her native place or genealogy. It aims to establish that the adopted person acknowledges origins to the adopter.

In my research site, many adult men and women had been adopted by relatives to be their successors. The adoption is normally announced at the time of a sedekah, or a special sedekah is organised to publicise it. After this, the adopted child declares that he or she is a descendant of the adopter. Thereafter, it is his/her duty to remember and make a visit to the dusun laman associated with the adopter.

Thus, it is evident that kinship relations are living representations of affinity to dusun laman, which also has close links with Gumay ancestors. There are a number of ways links with the Gumay ancestors are represented, such as through buildings or ancestral shrines. ${ }^{7}$ One of the most important physical structures in a Gumay village is the graveyard (Sakai 2009: 56-7). However, I have noted that, due to multiple relocations of a particular village, some Gumay villages retain their dedicated graveyard at the original village site. It is common for a Gumay person to be buried in their origin village even though they had long lived elsewhere, because there is a strong desire to maintain a close relationship with their dusun laman.

Reflecting on this discussion, it is essential to note that the ultimate Gumay origins are represented in the notion of dusun laman in three ways: first, a dusun laman is the hamlet or village where a person is born; second, it is the place associated with one of that person's parents or a place from which ancestors originated; third, a dusun laman is the imagined place to which they will return for their afterlife-an abode of the soul

7 See Collins's $(1979,1998)$ and Barendregt's (2008) work on South Sumatran traditional houses. 
of human beings (roh). The Gumay's neighbouring ethnic group the Besemah also use the concept of dusun laman as a place as well as a kin group (Barendregt 2008: 435).

\section{Dreams, visions and feelings: Fostering links to the dusun laman}

I will now present several ethnographic accounts that illustrate how dreams (mimipi), visions (ginaan) and feelings (rase) are used as a medium to maintain, revive or invent relations with origins or dusun laman. Overall, the most important concept to connect the living and the dead is roh, the soul of human beings. The closeness between the roh is considered to create strong affinity. Roh is distinguished from kundu, which determines a person's resilience and personality.

\section{The appointment of the Jurai Kebali'an}

The Jurai Kebali'an is the most important ritual role among the Gumay, and is strongly associated with his house. In other words, the Jurai Kebali'an can function best when he is within his home compound. Particularly important is the link between his bedroom and ancestral spirits. By tradition, the Jurai Kebali'an sleeps alone in his room, where the offerings are presented at the time of Sedekah Malam Empat Belas. His wife has her own room beside his bedroom; she is responsible for preparing the offerings for the rituals and enters his room only at the time of the rituals or when needed. It is a room kept for him as the Jurai Kebali'an, and should not be used for domestic or family matters. It is believed that ancestral spirits will visit the Jurai Kebali'an during his sleep to convey important messages. Gumay believe the spirits of human beings $(r o h)$ can travel during their sleep and, as a result, living spirits and those of the deceased can meet. Dreams therefore convey messages from the ancestors or deceased family members. One of the most important messages for the Jurai Kebali'an is who will succeed him.

It is expected the position will be inherited by one of the sons born to the Jurai Kebali'an's first wife. Where there is more than one son, it is expected the succession will be revealed by a dream or feeling experienced by the Jurai Kebali'an or his wife. In addition, a birthmark behind either ear, similar to the father's, is taken as evidence that a child is the successor. The succession is predetermined and not up to the individual to decide. For example, the previous Jurai Kebali'an, Pak Rumsyah, was not so 
interested in Gumay rituals or customary affairs when he was young. His elder brother, Wak Rustam Effendy, was much closer to their father and was very interested in knowing the history and customs of the Gumay people. However, their father announced that Rumsyah was going to succeed to the position of the Jurai Kebali'an, as he had a dream that showed this to be the case. Taking over his father's position was not what Rumsyah wished and he deliberately moved to Bandung after his marriage to look for a new life. During my frequent meetings with him between 1994 and 1996, he often told me that he had been plagued with illnesses and fevers while in Bandung and the doctors could not cure him. One day, out of desperation and hoping to get better, he vowed that he would go back to Lahat to take over his father's position. He later recovered from his illnesses and returned to Lahat with his wife.

Before his death in November 1999, Rumsyah did not clearly declare in public who would succeed him. There was speculation that his eldest son, Erlan, would take on the role as he was mature and had a calm and responsible nature. ${ }^{8}$ However, Rumsyah indicated that his youngest boy, Ical, was going to replace him-to the amazement of the Gumay community. This was because Ical was then still a junior high school student, while Erlan was in his mid-20s and married with a family. Rumsyah never declared that he had a dream nor did his wife; however, his wife vividly remembered that she had not been allowed to use contraceptives before Ical was born, as Rumsyah said she still had the responsibility to bear his replacement. Shortly after that, she became pregnant with Ical. While she was pregnant she was preparing to travel to Palembang and Rumsyah told her that she had to exercise caution as she was expecting his replacement. Such feelings were eventually taken as evidence that Ical would replace Pak Rumsyah. Before his sudden death in 1999, Rumsyah was asked to announce who was going to replace him. His brothers saw Rumsyah nodding when he was asked to confirm it would be Ical. The unclear circumstances surrounding the appointment of the incoming Jurai Kebali'an cast doubt on Ical, particularly because he was still a school-aged child. Ical remained single, so he played a de facto role as Jurali Kebali' an for nearly two decades, with his official inauguration on hold until he married. He was finally married in November 2015. A week after the wedding, the inauguration ceremony took place. Following this

8 Erlan was elected to be a Golkar Party member of the local parliament for two terms after the democratisation of Indonesia. 
event, Gumay ritual specialists were asked to report whether they had a dream revealing a suitable title to be given to the Jurai Kebali'an. Several meetings were held, but no conclusions were reached immediately, so the discussions continued for a few months until a decision was made that Ical's title would be Raden Arif, meaning wise and capable. Initially, the emphasis was given to mangkuk, meaning a bowl, symbolising generous acceptance and accommodation of the whole community, but the discussions eventually emphasised Arif. In summary, dreams and feelings form the most credible medium for conveying messages from the Gumay ancestors regarding the succession of the Jurai Kebali'an. This incident shows that the concept of roh, the human soul, is believed to enable a person to stay in this world while nyawe (life-sustaining principle) lasts, but roh can also drift during sleep. A roh continues to exist after death and may convey messages to Gumay descendants during a dream.

\section{The invention of the dusun laman}

Ancestors also convey messages to ordinary Gumay people through dreams and visions. The common theme of such dreams is to remember origins, which means Gumay people have to acknowledge and visit their origin village(s). As explained previously, there is no particular way to decide how to trace one's origins genealogically. Links are traced bilaterally to a particular ancestor and the origin village. The next case will summarise how Gumay people revive a link with their dusun laman and use figurative kinships to support their continuing links. Dreams and visions also play an important role, as outlined in an incident that took place in 1995 during my fieldwork.

Ali Asin knew he had a great-grandfather from Gumay; however, he had never visited any Gumay area in his life. He was married to Ross and they both lived in a village $130 \mathrm{~km}$ from Endikat Ilir. During 1995, they lost three grandchildren to illness. Following these deaths, Ross also became sick and fell unconscious, during which time she had a dream and spoke out loud that she acknowledged their origins in Gumay Talang. She promised she would visit and hold a sedekah in Gumay Talang. She also said that the medicine for her illness would be found $1 \mathrm{~km}$ from her home. The family later found some benzoin in a hut. In South Sumatra, benzoin is usually burnt to invoke ancestral spirits. The couple visited Gumay Talang 10 days later, but they could not find any relatives or genealogical connections with anyone and could not determine where to hold a gathering. Eventually, they went to the house of their son's best 
friend in Muara Tandi village. As their friendship was close, they formed an adopted sibling relationship (saudara angkat). Thus, it was logical to hold a gathering in Muara Tandi village, which the couple declared as their dusun laman at the time of the gathering.

\section{Dreams of returning to dusun laman}

It is reasonable to question whether interest in dusun laman has decreased under the increasing influence of Islam in contemporary Indonesian society. As explained earlier, the influence of Islam was strongly felt in wealthy regions of the South Sumatran highlands such as Pagar Alam, the heartland of Basemah region, as the number of pilgrims and the impact of modernist Islam (kaum muda) spread (Collins 1998: 13-14). I argue that the influence and importance of the dusun laman and ritual practice continue to dominate the everyday lives of the Gumay. Dreams and feelings continue to serve as an important medium for communication, as I outline below.

Although two families adopted me as a daughter, since 2008, I had not had a chance to visit Gumay Talang, and only maintained some communication via mobile phone calls and Facebook. One night in June 2015 while I was sleeping in Canberra, Mey, the daughter of my adopted sister Yulia, texted me from Gumay Talang. I had never received a text from her directly, but was aware she had married and had given birth to a baby boy. In my reply, I congratulated her and asked about her family. She immediately replied that her mother, Yulia, was being treated in hospital in Jakarta and had been calling my name during her sleep. Ical, Yulia's younger brother and now the de facto Jurai Kebali'an, was beside her bed and suggested that I should be contacted regarding Yulia's illness. For a month, I had some phone conversations with Yulia and her daughter regarding her illness. I later learnt that Yulia always displayed a photo of me with my son and husband in her room and explained to visitors that I was her 'sister' who lived overseas.

As her condition worsened rapidly, from late July to August 2015, I made a visit to see her in hospital—our first meeting for seven years—and saw Mey and her husband and son in Jakarta. The hospital did not provide much information about Yulia's condition, but seeing her indicated that her illness was terminal. While I was asking about Yulia's illness, Mey told me a story that indicated spirits of deceased relatives had visited her mother. It was in late June when Yulia was sitting on her bed after her bath in the early evening, with her legs swinging. Mey asked her mother what 
she was doing. Yulia responded that she had been invited to go somewhere far away by her elder sister Ayuk Oli and her father, Pak Rumsyahboth deceased close family members. Because Mey suggested that she should not join them, Yulia nodded, saying, 'Ok, it won't eventuate then' (tidak jadi, ya).

Another dream story was revealed the next day while I was at the hospital. I met Yulia's younger sister Novy and her husband, Andi, and their children. They had been visiting Yulia regularly as they lived in Jakarta. Fatigued, Andi decided to have a nap in the carers' rest room outside the ward.

While Andi was having a nap, I was alone with Yulia, who seemed to be sleeping, and I told her that I was going to Gumay Talang to see her (and my adopted) mother. I understood that she was getting old and her illness prevented her from leaving her house. I also learnt through my conversation with Novy's family that the most respected Jurai Tue of Mandi Angin village, Waq Mim, who was one of my discussants in Gumay Talang, was also unable to walk and remained confined to his house.

Later, I saw Andi sitting outside Yulia's ward chatting about various things. When I told him that I would visit Endikat Ilir to see our mother, he told me, with a surprised look, he had just had a dream during his nap in which Yulia had woken up to whisper into his ear that she wanted to go back to her house to see her mother and to visit her father's grave. It was taken as an indication of Yulia's strong wish to return to her dusun laman, which also could be interpreted as meaning her death was imminent and they endorsed the idea that I should visit the dusun laman on Yulia's behalf.

I left Jakarta the next day, as I learnt I could attend the Sedekah Malam Empat Belas in two nights. At the time of the monthly ritual, I was able to see the ritual specialists from the Gumay area who were also attending. My sudden return to Gumay Talang did not seem to cause surprise after nearly seven years of absence. I was showered with the same question: 'When did you return here?' On the night of the ritual, one of the Jurai Tue told me he had a feeling I was coming back to Gumay Talang and he told me a story related to the illness of Waq Mim. Earlier that year, he had become very ill with a high fever and fell unconscious. He was heard uttering unfamiliar words, which sounded like Japanese. People started to recite the Qur'an, as they thought Waq Mim might die at any moment. He later regained consciousness and recovered from his illness, although 
he had continuing problems with his leg. When he was asked to whom he was talking in his dream, he mentioned that I was visiting him. This incident was then taken as an indication that I would return to my dusun laman before long and people were expecting me.

Also important was the fact that this was the time it was announced in public that Ical would be married in November 2015 and would be inaugurated as the Jurai Kebali'an one week after the wedding. As an adopted member of the family, I was officially invited to attend Ical's wedding by one of the village elders because this ceremony would mark the most important event in the succession of Gumay customs. Yulia's family therefore thought she had wanted to see me before she died to inform me that her brother would finally be inaugurated in the coming November.

Yulia's close family members did not seem surprised by the fact that Yulia had become fatally ill after leaving her house the previous February. As her mother was ill and had lost her mobility, Yulia, as one of the daughters living in Endikat Ilir, had been responsible for preparing offerings at the time of the monthly Sedekah Malam Empat Belas ritual for the previous few years. However, when Mey was about to give birth, Yulia decided to move to Jakarta to look after her grandchild. To enable her to be away from her house in Endikat Ilir, Yulia had trained her half-sister and her brother's wife in how to prepare the offerings. She was heard to say that she would not be able to come back to Endikat Ilir after her grandchild was born, which was why she was teaching her sisters. It turned out that she was not able to return to Endikat Ilir at all after her grandson was born, due to her terminal illness. Her sister-in-law and her half-sister thought Yulia had experienced feelings that she would not return to her dusun laman to continue her ritual role, so she seemed to have prepared caretakers.

When Yulia died in early August 2015, her daughter informed me on the phone that her mother had 'returned'. Although wafat is increasingly the preferred Islamic expression among Muslims to refer to a death, pulang was used to refer to Yulia's death. Although Muslims prefer an immediate burial, her body was carried to Endikat Ilir village over 20 hours to be buried in her dusun laman, in the same graveyard as her father, in accordance with Gumay customs, followed by Qur'anic recitations at night. Yulia's soul (roh) is believed to visit her close family members, 
as she feels close and affectionate with them. Her daughter, in particular, feels much comfort as her mother continues to visit her during her sleep, indicating that she continues to care for her daughter's young family.

\section{Longing for a home}

Another death I experienced through my adopted family relationship was that of a younger sister, Ferry, in 2006. She was the daughter of Haji Hasan Basri, whose family I had lived with for two years in the town of Lahat. She became terminally ill with cancer while she was working in Jakarta. Her family wanted her to receive advanced cancer treatment in a hospital in Jakarta, but she was adamant she wanted to return to Lahat. Although she returned to her house, Ferry repeatedly said she did not feel she was at home and insisted that she still had to return home. Her house had undergone some renovations and, in an effort to help her feel at home, her family moved her bed between three different rooms. Despite these efforts, she continued to say she was not feeling at home right up to her death. Her family members, who had little involvement in Gumay adat, later felt that 'returning home' did not necessarily refer to the physical house or the town itself, but returning to the dusun laman to which both the living and the dead roh belong. Returning to the origin is the most cherished and comforting emotion for the Gumay.

\section{Feeling, ancestors and Islamisation}

The recent ethnographic examples of the Gumay I have presented show that strong affinity between a person and their ancestors as their origin is expressed through diverse feelings and revealed in dreams and visions. It is believed that the person's soul can travel and meet ancestral spirits during their sleep and important messages can be conveyed from ancestors to their descendants or among close family members in the form of a dream. Romantic and passionate feelings may be subdued or even discontinued if the person feels that ancestors do not approve of their intended marriage. Indeed, individuals may revoke an engagement that was based on romantic feelings (rasan muda) if either of the pair has a dream that indicates ancestors' disapproval of their marriage. 
It is also believed ancestors send messages to their descendants if there is a breach in observing Gumay adat matters. Thus, people are inclined to undertake rituals to seek forgiveness on behalf of their family members (jurai) if they suspect wrongdoing. Such wrongdoing could involve sexual relations outside marriage or not returning to their dusun laman for an extended time. Rare but not uncommon is someone going into a semiunconscious state, illustrated by the case of Ross, and conveying ancestral messages to their descendants.

A semi-unconscious state usually happens while someone is suffering from an illness, but can occur while someone is in the forest. Forests are believed to be the abode of natural guardian spirits who may feel invaded or disturbed for some reason. Such a transcendental state is expressed by terms such as ada yang masuk ('someone has possessed him'), kesurupan ('in a trance') or orang halus ('invisible being'), and people usually receive visions in which ancestors convey specific messages to their descendants to which the latter must adhere. For example, in August 1989, a ceremony to cleanse Gumay heirlooms, including weapons, was held in Lubuk Sepang village of Gumay Lembak, which resulted in the death of one participant and several others being injured. The procedures for the event were apparently modified from the original plan to accommodate the largerthan-expected crowd that had gathered to watch the ceremony. The venue was moved from a room in the house to the backyard, which was believed to be in breach of Gumay adat, and, in subsequent years, the event was returned indoors. ${ }^{9}$ During the 1989 event, one man had stabbed several participants, killing one, but he faced no criminal charges as he was deemed out of his mind and was sent to hospital for treatment. In 1995, when I interviewed the man in his home in Bunga Melur village of South Bengkulu, he said the only thing he remembered from the incident was seeing an orang halus wearing white clothes and gold bracelets descending from the sky. The Gumay ritual specialists interpreted the orang halus as an invisible ancestral spirit that had come to condemn the breach in the ritual's procedures. ${ }^{10}$

9 Other Gumay ritual specialists take the view that weapons should only be taken out into a yard at times of war, and the cleaning of weapons should be conducted indoors with the roof slightly ajar. 10 This incident can be considered an example of amuk or amok among Malay males, which involves a loss of self-control and an outburst of violent behaviour. 
Although dreams and visions are important for Gumay to communicate and express their connections with ancestors, references to visions and dreams are increasingly expressed privately while references to Islamic terms are chosen for use in public. As Indonesian Islam is becoming more orthodox (Sakai and Fauzia 2014), there is an increasing reluctance to admit openly that ancestral spirits determine the descendants' wellbeing and convey messages to descendants via dreams or feelings (Sakai 2017b), because such interpretations go against Islamic monotheism. Alternative, Islamic expressions such as ilham ('God's divine inspiration') and a general term such as sugesti ('feelings') have been used in public gatherings, while, in private conversation, people continue to maintain the importance of ancestral messages sent through visions in dreams.

A comparative analysis of ethnographic accounts of dreams among the Austronesians faces a significant difficulty as the Islamisation of contemporary society in South-East Asia has progressed to such a great extent and has decreased the use of expressions relating to connections with spirits and deities, particularly among Muslims in the public sphere. Thus, syncretic practices of religions well noted among the Javanese, as observed by Geertz (1960), have been marginalised in contemporary Indonesia (Hefner 2011). In Malaysia, reformist Islam spread with the strong backing of the state and swept away Malay shamanistic performances, which were deemed to be un-Islamic (Laderman 1991: 16-20). It is therefore no surprise that ethnographic accounts exploring the function of dreams, visions and feelings have received little attention to date in regions where the influence of Islam or Christianity is penetrating ever deeper. As a result, the importance of feelings communicated via dreams has continued to dominate life among indigenous populations such as the Temiar (Roseman 1991), is practised as part of local traditions of ziarah (a visit to various sacred sites or the graveyards of Islamic saints or ancestors) (Christomy 2008; Hellman 2013) or is carried on through spirit mediums (Bubandt 2009; Steadly 1993), while increasingly being contested by fundamentalist religious interpretations.

\section{Conclusions}

This chapter has analysed how Gumay people express their emotions, particularly their affinity with their origins, through the use of figurative kinship relations, visits to their dusun laman and ritual feast practices. 
The ethnographic accounts I have presented show that dreams and feelings are frequently used as mediums to convey important messages from a Gumay person, living or deceased, to their loved ones. While the living often use dreams as a medium to communicate with the spirits of the deceased in other Austronesian-speaking societies, ${ }^{11}$ the examples of Gumay show that dreams and feelings confirm and reinforce affinity between individuals while they are alive and also encourage Gumay people to remember their ancestral origins widely associated with a dusun laman. The Gumay commonly use the local word balik to express the return to origins, which can be translated into the standard Indonesian pulang. The meaning of this idea, however, refers not only to a return to the actual place of origin, but also to the notion of dusun laman — closely related kin members, living and deceased, as I have illustrated with Gumay examples. The Gumay therefore experience the closest affinity and affection when their soul can connect to places and incidents related to their ancestors. Thus, the Gumay continue to conduct monthly visits to the house of the Jurai Kebali'an and other rituals to celebrate and express their affinity to their origins.

\section{References}

Barendregt, Bart. 2008. 'The house that was built overnight. Guidelines on the construction and use of the southern Sumatran rumah uluan'. In Reimar Schefold, P. Nas and Gaudenz Domenig (eds) Indonesian Houses: Survey of vernacular architecture in western Indonesia, pp. 42964. Leiden: KITLV Press. doi.org/10.1163/9789004253988_015.

Beatty, Andrew. 1999. Varieties of Javanese Religion: An anthropological account. Cambridge: Cambridge University Press. doi.org/10.1017/ CBO9780511612497.

Bubandt, Nils. 2009. 'Interview with an ancestor: Spirits as informants and the politics of possession in North Maluku'. Ethnography 10(3): 291-316. doi.org/10.1177/1466138109339044.

Christomy, Tommy. 2008. Signs of the Wali: Narratives at the sacred sites in Pamijahan, West Java. Canberra: ANU E Press.

11 See Beatty (1999: 222-33) on how dreams are used to interpret the spirits of the deceased among Muslim Javanese. 
Collins, William. 1979. 'Besemah concepts: A study of the culture of people of South Sumatra'. PhD dissertation. University of California, Berkeley, CA.

Collins, William. 1998. The Guritan of Radin Sune: A study of the Besemah oral epic from South Sumatra. Leiden: KITLV Press.

Geertz, Clifford. 1960. The Religion of Java. Chicago: University of Chicago Press.

Hefner, Robert W. 2011. 'Where have all the abangangone? Religionization and the decline of non-standard Islam in contemporary Indonesia'. In Michel Picard and Rémy Madinier (eds) The Politics of Religion in Indonesia: Syncretism, orthodoxy, and religious contention in Java and Bali, pp. 71-91. London: Routledge.

Hellman, Jörgen. 2013. 'Meeting with ancestors: Contesting borders in Indonesian religion and politics'. Anthropological Forum 23(2): 178-97. doi.org.10.1080/00664677.2013.780964.

Laderman, Carol. 1991. Taming the Wind of Desire: Psychology, medicine and aesthetics in Malay shamanistic performance. Berkeley, CA: University of California Press. doi.org/10.1525/ california/9780520069169.001.0001.

Roseman, Marina. 1991. Healing Sounds from the Malaysian Rainforest: Temiar music and medicine. Berkeley, CA: University of California Press.

Sakai, Minako. 1997. 'Remembering origins: Ancestors and places in the Gumai society of South Sumatra'. In James J. Fox (ed.) The Poetic Power of Place: Comparative perspectives on Austronesian ideas of locality, pp. 42-62. Canberra: The Australian National University.

Sakai, Minako. 2002. 'Modernising sacred sites in South Sumatra? Islamisation and institutionalisation of ancestral places among the Gumai, Indonesia'. In Anthony J. S. Reid and Henri Chambert Loir (eds) The Potent Dead: Ancestors, saints and heroes in contemporary Indonesia, pp. 103-16. ASAA Southeast Asia Publication Series. Honolulu: University of Hawai'i Press. 
Sakai, Minako. 2003. 'Publicising rituals and privatising meanings: Gumai ritual practice in South Sumatra'. In Nicola Tannenbaum and Cornelia Kammerer (eds) Founder's Cults in Southeast Asia, pp. 159-83. New Haven, CT: Yale University Press.

Sakai, Minako. 2006. 'The origin structure of kute among the Gumai: An analysis of an indigenous territorial institution in the highlands of South Sumatra'. In Thomas Reuter (ed.) Sharing the Earth, Dividing the Land, pp. 39-64. Canberra: ANU E Press.

Sakai, Minako. 2009. 'From Bukit Seguntang to Lahat: Challenge facing Gumay ritual practice in the highlands of South Sumatra'. In Dominik Bonatz, John Miksic, J. David Neidel and Mai Lin Tjoa-Bonatz (eds) From Distant Tales: Archaeology and ethnohistory in the highlands of Sumatra, pp. 485-500. Cambridge: Cambridge Scholars Publications.

Sakai, Minako. 2017a. Kacant Tidak Lupa Kulitnya: Identitas Gumay, Islam, dan Merantau di Sumatra Selatan. Jakarta: Yayasan Pustaka Obor Indonesia.

Sakai, Minako. 2017b. 'Still remembering the origins: The continuity of syncretic Islamic practice among the Gumay (Gumai) in South Sumatra, Indonesia'. Indonesia and the Malay World 45: 44-65. doi.org/10.1080/13639811.2017.1274561.

Sakai, Minako and Amelia Fauzia. 2014. 'Islamic orientations in contemporary Indonesia: Islamism on the rise?'. Asian Ethnicity 15: 41-61. doi.org/10.1080/14631369.2013.784513.

Steadly, Mary Margaret. 1993. Hanging Without a Rope: Narrative experience in colonial and postcolonial Karoland. Princeton, NJ: Princeton University Press.

Waterson, Roxana. 1995. 'Houses, graves and the limits of kinship groupings among the Sa'dan Toraja'. Bijdragen tot de Taal-, Land- en Volkenkunde 15(2): 194-217. 
This text is taken from Expressions of Austronesian Thought and Emotions, edited by James J. Fox, published 2018 by ANU Press, The Australian National University, Canberra, Australia.

doi.org/10.22459/EATE.04.2018.02 